$10 \mid 2021$

Intelligence artificielle, pratiques sociales et politiques publiques

\title{
Usage of Geospatial Data and Artificial Intelligence Technologies and Evolution of Social Practices among Nigerian Youths
}

Utilisation des données géospatiales et des technologies d'intelligence artificielle et évolution des pratiques sociales chez les jeunes Nigérians

Die Nutzung von Geodaten und Technologien der künstlichen Intelligenz und die Entwicklung sozialer Praktiken unter nigerianischen Jugendlichen

Chidinma Henrietta Onwubere and Henry O. Osuji

\section{(2) OpenEdition}

Journals

Electronic version

URL: https://journals.openedition.org/ctd/5525

DOI: $10.4000 /$ ctd. 5525

ISSN: 2491-1437

\section{Publisher}

Chaire Unesco Pratiques émergentes en technologies et communication pour le développement

Printed version

ISBN: 2491-1437

Electronic reference

Chidinma Henrietta Onwubere and Henry O. Osuji, "Usage of Geospatial Data and Artificial Intelligence Technologies and Evolution of Social Practices among Nigerian Youths", Communication, technologies et développement [Online], 10 | 2021, Online since 20 May 2021, connection on 27 May 2021. URL: http://journals.openedition.org/ctd/5525 ; DOI: https://doi.org/10.4000/ctd.5525

This text was automatically generated on 27 May 2021

Communication, technologies et développement 


\section{Usage of Geospatial Data and Artificial Intelligence Technologies and Evolution of Social Practices among Nigerian Youths}

Utilisation des données géospatiales et des technologies d'intelligence artificielle et évolution des pratiques sociales chez les jeunes Nigérians

Die Nutzung von Geodaten und Technologien der künstlichen Intelligenz und die Entwicklung sozialer Praktiken unter nigerianischen Jugendlichen

Chidinma Henrietta Onwubere and Henry O. Osuji

\section{Introduction}

1 Adoption of Geospatial Data \& Artificial Intelligence Technologies (GDAIT) as social development tools was done without the intended users studying the efficacy of the equipment prior to their use. This creates some social disorder, making the society lose some benefits of GDAIT as the users are ill-prepared for the adverse effects that may arise from the technologies. Hall, 2019 observed that "the ultimate success of artificial intelligence (AI) will depend on how well society is prepared for its widespread application". Low infrastructure countries like Nigeria lacking adequate tools for filtering and censoring information usually misapply these valuable technologies and end up experiencing "significant social and economic disruption."

GDAIT are often used as organs of information sourcing and dissemination, social enlightenment and mobilisation, of societal growth and development. These functions make them an important factor in the relationship between the different arms of the society. Being a major phenomenon that has globally transformed the interaction, communication and sharing of information amongst people in this 21st century 
(Olujide, Adeyeimi, \& Gbadeyan, 2010), researchers need to pay particular attention to the adoption and use of GDAIT through social media platforms.

3 Social media interactions and the manner in which information is presented depend on the varied perspectives and "building" of shared meaning among communities (Wattal et al. 2010 ; Kaplan \& Haenlein, 2010). Unfortunately, over-dependence on these shared experiences over the social media compels ignorant youths to accept the alien messages and communication they access from the social media platforms as reality, a reflection of George Gerbner's (1994) “cultivation perspective". These platforms include Facebook, YouTube, Twitter, Blogs, MySpace, LinkedIn, etc. By July 2020, over 27 million Nigerians were using Facebook (Statista, 2020); worldwide, more than 800 million people in 2011 (Facebook) while Twitter had over 200 million accounts (HuffPost Tech, 2011). So, social media are fantastic tools for communicating with large and spatially dispersed audience among whom are Nigerian Youths (Onwubere \& Osuji : 2020).

4 Accordingly, Wigand et al., (2010); McAfee, (2006) posited that social media have become a natural part of the everyday lives of people worldwide. Recently, social media usage has grown rapidly to become object of scientific analysis. Since according to Dentzel (1983), the internet is now our preferred medium of everyday communication, the obsessive usage of internet facilities by youths is likely to evolve novel social practices among them.

5 Several researches have confirmed that youths love to use GDAIT because of their massive deployment of technologies using big data and algorithms, coupled with their unrestrained access to modern internet-connected appliances. Quaglio (2019) posited that "Extensive internet use, of social media in particular, is correlated with loneliness and social isolation. Intimate relationships can be degraded by internet use, cyberbullying, cyber-stalking and online predation, and this affects a significant percentage of internet users". These are strange to the trado-African setting. In agreement, Onwubere \& Osuji (2020) confirmed that Nigerian youths are excessively exposed to GDAIT such that they influence their perception of social relations negatively.

6 This raises concerns for the stability of the erstwhile peaceful and anthropocentric traditional African/Nigerian setting. These changes in social communication are also significant to the evolution of alien social practices that may accompany Nigerian youths' negative perception of social relations. The spate of rape and sexual misdemeanor among Nigerian youths, suicidal tendencies, impunity and recklessness in behaviour are some grave novel/alien social practices emanating from indiscriminate and uncensored use of GDAIT by youths. The facts supporting this assertion are contained in an earlier study by Onwubere \& Osuji (2020).

7 Dentzel (1983) observes that Digital Technologies play vital roles in empowering individuals and communities, hence, the application of these technologies is "expected to increase productivity and competitiveness, change education and cultural systems, stimulate social interchange and democratise institutions". Nevertheless, these laudable technologies and their roles also permit the pollution of minds and disruption of social relations in record time.

8 Researches show that excessive exposure to electronic screen causes depression and suicidal tendencies as smartphones are causing less sleep. Twenge : 2017, observes that this alone could explain why depression and suicide increased so suddenly, and that 
teens spent less time on activities known to benefit mental health (in-person social interaction) but more time online on activities that may harm it.

Digital illiteracy constitutes a big problem in low infrastructure countries like Nigeria where young and old do not have the requisite Media and Information Literacy (MIL) Education to discern between 'fake news' and reliable news. The tendency is that there will be upsurge in youthful exuberances, since youths can easily publish and widely express themselves positively or negatively through electronic media. These novel exuberant behaviours are alien to the traditional Nigerian society where discretion and restraint are upheld. So, they have grave implications for social practices and social stability in Nigeria.

This study investigates the relationship between the Usage of GDAIT by Nigerian youths and the Evolution of Social Practices. Gerbner's Cultivation (1973), Bandura's Observational Learning (1979) and Veblen's Technological Determinism (1926) theories serve as theoretical frameworks for the study. Since education is the greatest socialising factor for youths, and youths being the greatest users of Artificial Intelligence-based digital tools, institutions of higher learning have logically become the best and the most fertile ground to study the influence of GDAIT on socialisation and observe the evolution of social practices among youths. Hence, a survey of 300 students of the National Open University of Nigeria (NOUN) in Abuja, the Federal Capital Territory of Nigeria was conducted to elicit information from the youths, using the stratified random sampling technique. Results were analysed to ascertain the relationship between the usage of GDAIT by Nigerian youths and the evolution of social practices. Following survey results, recommendations were made to mitigate the damaging influence of the use of GDAIT on the socio-political order.

\section{Operationalisation of concepts}

Intelligence : is the capacity to do the right thing at the right time, in a context where doing nothing (making no change in behavior) would be worse.

Artificial Intelligence : refers to the simulation of human intelligence in machines that are programmed to think like humans and mimic their actions.

Fake News : violent message whose originator's aim is to mislead the receiver in order to create some disadvantage or some undue advantage for some people or entities.

Geospatial Data : information with a geographic aspect attached to it, meaning that the records in the information have coordinates, an address, included with them.

Social Media : a group of Internet-based applications that allow for the creation and exchange of user-generated content by using geospatial data and artificial intelligence technologies.

Social Innovation : is the process of developing and deploying effective solutions to challenging and often systemic social and environmental issues in support of social progress.

17 Social practices : refer to everyday practices and the way these are typically and habitually performed in a society. Such practices (e.g. going to work, cooking, taking shower) are meaningful to people as parts of their everyday life activities. 


\section{Aim and Objectives of Paper}

\section{Aim of Paper}

18 The aim of this study is to investigate the relationship between the exposure of Nigerian youths to Geospatial Data and Artificial Intelligence Technologies and the Evolution of Social Practices among Nigerian Youths.

\section{Objectives of the Paper}

\section{The paper tried to}

1. Establish the relationship between the Nigerian tertiary students' usage of GDAIT and their development of novel social practices.

2. Investigate the relationship between these youths' demographic variables (age, gender \& socio-economic background) and their exposure to social media influence on the one hand, and the evolution of novel social behaviours/practices such as: rape, murder, suicide, stalking, self-publishing etc. in them on the other hand.

21 3. Ascertain if the usage of GDAIT influences and germinates novel social interactions among Nigerian youths.

\section{Research Questions}

Onwubere and Osuji (2020), established that Nigerian youths (mainly 4th \& 5th year undergraduates aged 20 and above, who own smartphones and use them for at least 4 hours daily, 7 days a week) are fully exposed to GDAIT and at high intensity; that intensive exposure to GDAIT affects their judgement of truth and of the possibility of certain events happening, while their alertness to social media-based violence makes them perceive social relations negatively and this influences the way they relate with society as they perceive social relations as somewhat inhuman, impersonal, cold, electronic and as distant relationship devoid of sensitivity or emotion. The present paper goes further to identify the ways in which the usage of GDAIT induces positive or negative evolution of social practices by Nigerian youths and the consequences of the evolution. Hence, the research questions aim at tracking the social practices and the domains concerned by this evolution, viz :

1. How does the level of exposure of Nigerian youths to GDAIT (especially social media) affect their interactions with their communities?

2. How do Nigerian youths exposed to GDAIT react to their social practices? Do they identify with existing social norms or evolve new social practices?

3. Is there any relationship between the usage of GDAIT by Nigerian youths and their portrayal of alien/novel social practices? 


\section{Theoretical Frameworks}

The relevant mass communication theories are the Cultivation Theory (1976), Observational Learning Theory $(1973,1983)$ and the Technological Determinism Theory (1926). But the topic focuses on Cultivation Theory.

\section{(a) George Gerbner's cultivation theory (1976) :}

This theory considers how the excessive exposure to the media, especially through the television and other interactive media subtly shapes the users' views of the world and social reality. It posits that viewers learn "facts about the real world through observing the world of television." The viewer automatically stores memory traces got from the TV and later uses the stored information to formulate beliefs about the real world. The concrete base behind this cultivation theory is that the more viewers watch TV, the more their faith in the TV version of reality. (Gerbner, G \& Gross L, 1976). This also applies to the use of the various GDAIT gadgets as the excessive exposure to them causes dependence on the false information that most of the social media platforms carry as fake news (Onwubere \& Osuji : 2020).

Other theories are :

(b) Bandura's Observational Learning Theory $(1973,1983)$ :

This theory states that viewers, especially children, learn and imbibe certain behaviours by observing and copying some television stars who they consider as their role models. Hence, people can learn aggressive behaviours by observing aggression on Television. Nigerian youths imbibe a lot of alien social practices from the GDAIT that they are excessively exposed to.

(c) Thorstein Veblen's Technological Determinism Theory (1926) also called Medium Theory :

Technology is viewed as the driving force of culture in a society. So, technology in any given society defines its nature. The new media are not only an addition to existing media, they are also new technologies and therefore do have a deterministic factor as well. Marshall McLuhan made a famous statement that "the medium is the message." This means that the medium used to communicate influences the mind of the receiver. Hence, the excessive use and dependence on GDAIT by Nigerian youths influences their concept of social reality and thus, greatly affects their behaviours which they exhibit through their physical actions.

\section{Method of Study}

The survey research design was adopted. The population of study was students of Nigerian Universities. The sample was drawn from 550,000 students of the National Open University of Nigeria (NOUN), a mega University in the Federal Capital Territory of Nigeria. This is because, first, the University is the largest in the country, with study centres all over the federation, and has a wide range of students presumed to be familiar with the tools of communication on the different social networks. Secondly, the researchers have access to all students' registration documents that enabled scientific selection of respondents. Through the Online Survey Monkey platform, copies of questionnaires were distributed to 300 respondents using a simple random sampling 
method. However, only 280 responses were received for analysis, which is $93 \%$ response rate.

\section{Presentation of Survey, Data Analysis and Interpretation}

The survey questionnaire comprising of 35 questions was designed to provide answers to the three research questions which were framed to cover the objectives of the paper. For each Research Question, several corresponding survey questions were asked such that the survey responses will reinforce each other to make the answers to the Research Questions very reliable. In this space-limited paper, it is not feasible to fully present or append all the survey data ( 35 questions with multiple responses) in a table format. Readers are hence encouraged to contact the authors by email for the full survey data (cf References).

\section{Research question 1}

"How does the level of exposure of Nigerian youths to GDAIT (especially social media) affect their interactions with their communities?"

\section{Data analysis}

From the 10 corresponding survey questions $(14,16,18,19,20,21,22,31,32,35)$, these results were obtained :

i. $76.7 \%$ (161 of 210 respondents) feel scared because of the possibility of bad behaviours from members of the society.

ii. $45.2 \%$, highest score for the question, (95 of 210 ) hesitate to relate with people in their community because they are aware that the community people say negative things about one another.

iii. $72.8 \%$ (147 of 202) feel encouraged to relate with people in their community because they are informed that the community people support one another in times of difficulty.

iv. $79.7 \%$ (161 of 202) mix up freely with their friends and relatives because they know the people always work harmoniously together.

v. $66.8 \%$ (135 of 202) freely participate in their community activities because they are aware that members of the community are always happy and sharing things together.

vi. $82.4 \%$ (154of 187) agree that the use of online platforms for meetings or conferences makes it easier for them to participate in community or social activities.

vii. $51.9 \%$ (97 of 187) are motivated to and attend or participate at greater number of

get-togethers and social activities (religious worships, weddings, political activism, sports etc) because they are organised online.

viii. $79.7 \%$ (149 of 187) agree that their access to GDAIT provides them hitherto inexistent opportunities to socialise with many more people and organisations and helps them to do various forms of digital (online) business. 
ix. $92.5 \%$ (173 of 187) confirm they are more conscious and careful about their physical appearance and gestures when placing video calls than when placing voice phone calls. x. $70.6 \%$ (132 of 187) state that it is easier and simpler for them to approach other youths for social relationships if or when they use a social media platform than trying a physical face-to-face approach.

\section{Data interpretation \& answer to research question 1}

For all the survey questions addressing research question 1, all the highest or majority scores jointly indicate that it is the exposure to GDAIT that facilitated the awareness of respondents (the youths) about the behaviours and social activities of their communities. The community's behaviour or type of social activity then determines if or not and how the respondents will participate or relate with their communities. Youths become more attentive to their physical appearance and gestures because they realise the great exposure-and-broadcast capabilities of GDAIT through social media. The socio-economic benefits or opportunities and the online technologies deployed by using GDAIT to organise community events also help to collapse the barriers that would have discouraged youths from participating in community events which may be academic, religious, political, economic, sociocultural or professional.

\section{Research question 2}

"How do Nigerian youths exposed to GDAIT react to their social practices? Do they identify with Existing Social Norms or Evolve New Social Practices ?"

\section{Data analysis}

From the 22 corresponding survey questions $(8,9,10,14,16,18,19,20,21,22,23,24,25$, $26,27,28,29,31,32,33,34,35)$, these results were obtained :

i. Purposes for which Nigerian youths use messages or information got from social media are Educational Purposes 54.1 \% (119 of 220), Upgrade Yourself $51.8 \%$ (114 of $220)$, Keeping Abreast of global social events $50 \%$ (110 of 220 ).

ii. $86.8 \%$ (191 of 220) disseminate the information they receive to other people.

iii. $82.1 \%$ (174 of 212 ) disseminate messages they receive to other people by text, photo or video through Social Media Platforms.

iv. $76.7 \%$ (161 of 210 respondents) feel scared because of the possibility of bad behaviours from members of the society.

v. $45.2 \%$, highest score for the question, (95 of 210) hesitate to relate with people in their community because they are aware that the community people say negative things about one another.

vi. $72.8 \%$ (147 of 202) feel encouraged to relate with people in their community because they are informed that the community people support one another in times of difficulty.

vii. $79.7 \%$ (161 of 202) mix up freely with their friends and relatives because they know the people always work harmoniously together. 

and a great majority of youths disseminate messages they receive to others through social media platforms. The traditional norm in learning is by face-to-face interpersonal or group discussions, but GDAIT has made it possible and cost-effective for youths or learners to be self-reliant. 
Traditionally, information sharing is done by personal visits and discussions with friends, not by electronic exchanges. Disseminating information mainly through social media platforms increases the spread of fake news which is the principal danger and evil of GDAIT, especially in societies lacking effective means to curb its disastrous consequences.

Though majority of youths hesitate because they are scared by bad behaviour and social media malpractices, they finally participate in social events when organised online because of the psychological, social and economic facilitations, benefits or opportunities presented by GDAIT-aided social events. Majority of the youths who cannot afford to participate feel it badly, socially and psychologically with possibility of getting depressed or engaging in economic malpractices to finance their way into the "high society" if the digital discrimination persists.

The risk of physically meeting hateful and hated persons in social activities is higher when people attend in person, and this risk usually dissuades youths from participating, whereas virtual participation eliminates the risk and promotes freer verbal expression by participants without fear of instant physical aggression.

\section{Research question 3}

"Is there any relationship between the usage of GDAIT by Nigerian youths and their portrayal of alien/novel social practices?"

\section{Data analysis}

From the 12 corresponding survey questions $(8,10,16,17,18,19,20,21,22,31,32,35)$, these results were obtained :

i. Purposes for which Nigerian youths use messages or information got from social media are Educational Purposes 54.1\% (119 of 220), Upgrade Yourself 51.8 \% (114 of $220)$, Keeping Abreast of global social events $50 \%$ (110 of 220 ).

81 ii. $82.1 \%$ (174 of 212 ) disseminate messages they receive to other people by text, photo or video through Social Media Platforms.

iii. $45.2 \%$, highest score for the question, (95 of 210) hesitate to relate with people in their community because they are aware that the community people say negative things about one another.

83 iv. $77.6 \%$ (163 of 210 ) disagree that they avoid family members because they frequently receive messages that show that their family members disagree with one another most of the time.

v. $72.8 \%$ (147 of 202) feel encouraged to relate with people in their community because they are informed that the community people support one another in times of difficulty.

vi. $79.7 \%$ (161 of 202) mix up freely with their friends and relatives because they know the people always work harmoniously together (no sabotage, jealousy \& disdain against others' efforts).

vii. $66.8 \%$ (135 of 202) freely participate in their community activities because they are aware that members of the community are always happy and sharing things together. 

Cultivation Theory, Nigerian youths internalise alien cultures and novel practices which distance them from the anthropocentric values of Nigeria's traditional society. Even when the novel social practices hurt or harm, youths consider them as "the new normal". Actions, behaviours and events that were traditionally considered as violent, immodest and unacceptable in social relations are now vulgarised by social media and youths intensively exposed to GDAIT now see them as "normal" and therefore logically acceptable. This Gerbner's Theory phenomenon affects all domains of life and livelihood, hence creating a huge fault line between the sociocultural values of traditionalists (elders) and the progressives (youths). If the trend continues, sooner or later, parents and grand-parents may no longer "understand" their children and grand-children.

\section{Discussion of Findings}

Traditional social practices in Nigerian society are generally anthropocentric, that is, human-to-human relationships in which the human factor is essential, while social practices generated or aided by GDAIT are "electrocentric" because they depend on electronic devices connected by internet or telephony. The evolution or transition of social practices from anthropocentric to electrocentric creates socio-economic and societal discrimination because digital accessibility or affordability now defines or determines people's degree or extent of socialisation in all its ramifications. This evolution brings up the concept of digital quality of life which is now a status symbol 
and yardstick by which youths measure their comfort, self-esteem and psychosocial balance.

The quasi social stability guarded by anthropocentric social practices is being eroded by the novel advantages presented by GDAIT, advantages which attract Nigerian youths to electrocentric social practices. Youths are generally on the fast track and appreciate how GDAIT collapse time and distance, making them less of constraints to social interactions and activities as youths can do many distant activities in a day. Inertia and psychological barriers are broken for introverted and shy youths who usually will shy away from social events that demand physical presence with some socially-correct attitudes like showing a smiling face, engaging in conversations, dancing, etc.

The manner in which education socialises youths is changing as they are cultivating the habits of self-learning, online streaming of lectures, etc which can compensate the consequences of physical absence at lectures. But self-isolation is antithetical to socialisation, and anything that reduces the possibility of physical learning in group also limits the power of education to socialise youths. However, business-oriented youths called "influencers" use novel social practices borne out of GDAIT (blogs, social media) to induce their peers to buy products and services of companies that pay the influencers for that online marketing service.

\section{Conclusion and Recommendations}

8 Human-centred social practices are fast evolving into electronic-centred social practices due to massive deployment of GDAIT and intensive exposure of Nigerian youths to them. To take full advantage of GDAIT and minimise its disadvantages, focus must be on :

(a) Reducing the dangers of fake news - the greatest threat

Fake news grows with social media usage. Onwubere \& Osuji (2020) did a predictive profiling of youths susceptible to trigger violent protests such as the notorious violent youth protests in Nigeria called "\#ENDSARS Protests" done in October 2020, ascertained to have been organised through social media and aided by the use of fake news. The protests caused widespread destruction of private and public properties across Nigeria. That "radical youth" profile is reconfirmed in this research and is " 4 th \& 5th year tertiary students aged 20 years and above, who own smartphones and use them for at least 4 hours daily, 7 days a week".

As nothing yet can stop the deployment of GDAIT in Nigeria, this profiling of agents of social and political activism constitutes a useful tool for preventing socio-political disorder. Many means of controlling fake news have been proposed by various entities. This paper adds a metaphoric model for achieving thorough investigation of fake news and their authors or disseminators. Termed the "scope-instruments model for tracking fake news", it consists of using the methods or techniques of observational instruments (microscope, periscope, telescope, kaleidoscope) to investigate, identify, observe and study fake news, their nature, origin or disseminators in view of controlling or managing them. Microscope technique (microscopy) helps to reveal covert aspects or hidden details of fake news at close observation. Periscopy and telescopy will discretely detect nascent fake news from afar and may nib them in the bud. Kaleidoscopy will display the nature and pattern, therefore the level of dangerosity of fake news. 
(b) Improving infrastructures for internet and telephony

Affordable broad-band internet access in homes and public places and rural telephony will enhance youths' digital quality of life by improving digital accessibility.

(c) Public orientation on internet security and cybercrimes

This will create awareness among naïve people who do not know the dangers or risks of using internet and social media. They would thereafter be able to take responsibility for their acts on internet.

\section{BIBLIOGRAPHY}

Bandura, A. (1994) "Social Cognitive Theory of Mass Communication". In J. Bryant and D. Zilman (eds). Media Effects : Advances in Theory and Research, pp. 61-90 Hillsdale ; NJ : Erlbaum.

Christakis, N. A., and Fowler, J. H. (2010). Connected: The surprising power of our social networks and how they shape our lives. London : Harper Press.

Demnievska, E. (2018). The UNESCO Courier • July-September $2018 \mid$ 3, pp1-72.

Dentzel Zaryn (1983). "How the internet had changed everyday life". Downloaded on Tuesday, $22^{\text {nd }}$ December, 2020 from es.wikipedia.org/wiki/Zaryn_Dentzel.

Gerbner, G and Gross L, (1976) in Onwubere, C.H (2012). Exposure of Nigerian Children to Television and Video Violence and Their Perception of Social Relation. Germany : Lambert Academic Publishing GmbH \& co KG.

Gerbner, G., Gross, L, Morgan, M., and Signorelli, N. (1994). "Growing up with television" : The cultivation perspective.

Hall, C (2019). “Thoughts on AI's Potential for Social and Economic Disruption”. Posted November 5, 2019 in Data Analytics \& Digital Technologies.

Kaplan, A. M., and Haenlein, M. (2010). Users of the world, unite! The challenges and opportunities of social media. Business Horizons, vol. 53 : 59-68.

Kaplan, A. M., and Haenlein, M. (2010). In Oshibe, N.I. (2020) Social Media and Political Mobilisation for The 2019 General Elections in Ebonyi State. An unpublished B.Sc thesis of National Open University of Nigeria.

Lemack and Hall (2013). In Siraj (2017) O. A. "Social Media and Social Vices : Curtailing Youth Violent Extremism through MIL Strategies".

McCarthy, J. (November 12, 2007). "What Is Artificial Intelligence?

Olujide, Adeyeimi, \& Gbadeyan, (2010). In Oshibe, N.I. (2020) Social Media and Political Mobilisation for The 2019 General Elections in Ebonyi State. An unpublished B.Sc thesis of National Open University of Nigeria.

Onwubere, C.H and Osuji, H O. (2020) “Nigerian Youths' Exposure to Geospatial Data and Artificial Intelligence Technologies : Cultivation Theory and Perception of Social Relations”. 
UNESCO : International Council for UNESCO Chair in Emerging practices in Information and Communication Technologies for Development. March 2019.

Onwubere, C.H and Osuji, H O. (2021), Survey Questions and Responses (unpublished) for the study “... Geospatial Data \& Artificial Intelligence Technologies and Evolution of Social Practices

...”. Contact emails : conwubere@noun.edu.ng ; osuji.fnieb@wanadoo.fr

Poole, Mackworth \& Goebel (1998). "Definition of AI as the study of intelligent agents", www.en wikipedia.org//wiki/artificial_intelligence\#CITERFPPooleMackworthGoebel. Downloaded December 15, 2020.

Quaglio, G (2019). “Information Technology, internet, internet use'. Posted by Scientific Foresight (STOA) - February 18, 2019. Singer, D.G. and Singer, J. L. (2001). Handbook of Children and The Media. London : International Educational Publisher, Sage Publications.

Statista, July 2020 : https://www.statista.com/statistics/972927/number-of-facebook-usersnigeria/

Twenge, J (2017). en.wikipedia.org > wiki > Social practice.

Wattal et al. (2010). In Oshibe, N.I. (2020) Social Media and Political Mobilisation for The 2019 General Elections in Ebonyi State. An unpublished B.Sc thesis of National Open University of Nigeria.

\section{ABSTRACTS}

In the words of Zaryn Dentzel (1983), an erudite Spanish diplomat, technocrat and educationist, "The Internet has turned our existence upside down. It has revolutionized communications, to the extent that it is now our preferred medium of everyday communication." This assertion is very true when we consider the obsessive usage of the various internet facilities by youths of contemporary day among who are Nigerian youths. Several researches have confirmed that youths are greatly endeared to the use of geospatial data due to the massive deployment of technologies that use the big data and algorithms, coupled with their unrestrained access to mobile and semi-mobile internet-connected appliances and technological gadgets of this 21st century. The study of Onwubere and Osuji (2020) particularly confirmed the fact that Nigerian youths are excessively exposed to these Geospatial Data and Artificial Intelligence Technologies (GDAIT) to the extent that they influence their perception of Social Relations, negatively. This, of course, is of great concerns for the stability of the erstwhile peaceful and anthropocentric Traditional African/Nigerian Setting. These changes in social communication are also of particular significance to the Evolution of Alien Social Practices that may accompany Nigerian youths' negative perception of social relations. Dentzel again, observed that Digital Technologies play vital roles in empowering individuals and communities, hence, the application of these technologies is "expected to increase productivity and competitiveness, change education and cultural systems, stimulate social interchange and democratise institutions". Nevertheless, these laudable technologies and their roles also permit the pollution of minds and disruption of social relations in record time. Digital illiteracy may constitute a serious problem in low infrastructure countries like Nigeria where there are no adequate tools for filtering and censoring information and where children, youths and adults do not even have the requisite Media and Information Literacy (MIL) Education to discern the difference between 'fake news' and reliable news. The tendency is that, there will be an upsurge in youthful exuberances, since youths can easily publish and widely express themselves positively or negatively through these electronic media, unfettered by any financial constraints. These exuberant behaviours definitely have grave 
implications for social practices and social stability in Nigeria. This study investigates the relationship between the Usage of Geospatial Data and Artificial Intelligence Technologies (GDAIT) by Nigerian Youths and the Evolution of Social Practices. The Gerbner's Cultivation, Bandura's Observational Learning and Veblen's Technological Determinism theories serve as theoretical frameworks for the study. Since education is the greatest socialising factor for youths, and young adult students being the greatest users of modern Artificial Intelligence-based digital tools, institutions of higher learning have logically become the best and the most fertile ground to study the influence of GDAIT on socialisation and observe the evolution of social practices among youths. Hence, a survey of 300 undergraduate students in Abuja, the Federal Capital Territory of Nigeria was conducted to elicit information from the youths, using the Stratified Random Sampling technique. Results will be analysed using appropriate statistical approaches, essentially, SPSS, to ascertain the relationship between the Usage of Geospatial Data and Artificial Intelligence Technologies (GDAIT) by Nigerian Youths and the Evolution of Social Practices. Following survey results, utilitarian, constructive and constraining recommendations will be made to mitigate the damaging influence of the use of Geospatial Data and Artificial Intelligence Technologies on the socio-political order.

Selon Zaryn Dentzel (1983), diplomate, technocrate et pédagogue espagnol érudit, "Internet a bouleversé notre existence. Il a révolutionné les communications, à tel point qu'il est désormais notre moyen de communication privilégié au quotidien". Cette affirmation est vraie si l'on considère l'utilisation obsessionnelle des divers dispositifs Internet par les jeunes d'aujourd'hui, dont les jeunes Nigérians. Plusieurs recherches ont confirmé que les jeunes sont très attachés à l'utilisation des données géospatiales en raison du déploiement massif de technologies qui utilisent le big data et les algorithmes, et en raison de leur accès illimité aux appareils mobiles et semi-mobiles connectés à Internet et aux gadgets technologiques de ce $21 \mathrm{e}$ siècle. L'étude d'Onwubere et Osuji (2020) a particulièrement confirmé le fait que les jeunes Nigérians sont excessivement exposés à ces technologies de données géospatiales et d'intelligence artificielle (GDAIT) au point qu'elles influencent négativement leur perception des relations sociales. Ceci est très préoccupant pour la stabilité du cadre traditionnel africain/nigérian, autrefois pacifique et anthropocentrique. Ces changements dans la communication sociale sont également d'une importance particulière pour l'évolution des pratiques sociales étrangères qui peuvent accompagner la perception négative des relations sociales par les jeunes Nigérians. Dentzel a également observé que les technologies numériques jouent un rôle essentiel dans l'autonomisation des individus et des communautés, et que l'application de ces technologies devrait "accroître la productivité et la compétitivité, modifier les systèmes éducatifs et culturels, stimuler les échanges sociaux et démocratiser les institutions". Néanmoins, ces technologies louables et leurs rôles permettent également de polluer les esprits et de perturber les relations sociales en un temps record. L'analphabétisme numérique peut constituer un grave problème dans les pays à faible infrastructure comme le Nigeria, où il n'existe pas d'outils adéquats pour filtrer et censurer l'information et où les enfants, les jeunes et les adultes ne disposent même pas de l'éducation aux médias et à l'information, nécessaire pour faire la différence entre les "fake news" et les informations fiables. La tendance est à la recrudescence des exubérances juvéniles, puisque les jeunes peuvent facilement publier et s'exprimer de manière positive ou négative par le biais de ces médias électroniques, sans aucune contrainte financière. Ces comportements exubérants ont certainement de graves répercussions sur les pratiques sociales et la stabilité sociale au Nigeria. Cette étude examine la relation entre l'utilisation des données géospatiales et des technologies d'intelligence artificielle (GDAIT) par les jeunes Nigérians et l'évolution des pratiques sociales. Les théories de la culture de Gerbner, de l'apprentissage par observation de Bandura et du déterminisme technologique de Veblen servent de cadres théoriques à l'étude. L'éducation étant le plus grand facteur de socialisation des jeunes, et les jeunes étudiants adultes 
étant les plus grands utilisateurs d'outils numériques modernes basés sur l'intelligence artificielle, les établissements d'enseignement supérieur sont logiquement devenus le meilleur et le plus fertile terrain pour étudier l'influence du GDAIT sur la socialisation et observer l'évolution des pratiques sociales chez les jeunes. Une enquête a donc été menée auprès de 300 étudiants de premier cycle à Abuja, Territoire de la Capitale Fédérale du Nigeria, afin d'obtenir des informations auprès des jeunes, en utilisant la technique de l'échantillonnage aléatoire stratifié. Les résultats seront analysés à l'aide d'approches statistiques appropriées, essentiellement SPSS, afin de déterminer la relation entre l'utilisation des GDAIT par les jeunes Nigérians et l'évolution des pratiques sociales. Suite aux résultats de l'enquête, des recommandations utilitaires, constructives et contraignantes seront faites pour atténuer l'influence néfaste de l'utilisation des GDAIT sur l'ordre socio-politique.

Mit den Worten von Zaryn Dentzel (1983), einem gelehrten spanischen Diplomaten, Technokraten und Pädagogen, "Das Internet hat unsere Existenz auf den Kopf gestellt. Es hat die Kommunikation revolutioniert, und zwar in einem Maße, dass es heute unser bevorzugtes Medium für die tägliche Kommunikation ist." (Dentzel 1983; eigene Übersetzung aus dem Englischen). Diese Behauptung ist sehr zutreffend, wenn wir die obsessive Nutzung der verschiedenen Interneteinrichtungen durch die Jugendlichen von heute betrachten, zu denen auch die nigerianischen Jugendlichen gehören. Mehrere Untersuchungen haben bestätigt, dass Jugendliche aufgrund des massiven Einsatzes von Technologien, die Big Data und Algorithmen nutzen, in Verbindung mit ihrem uneingeschränkten Zugang zu mobilen und semi-mobilen internetfähigen Geräten und technologischen Gadgets dieses 21. Jahrhunderts stark auf die Nutzung von Geodaten fixiert sind. Die Studie von Onwubere und Osuji (2020) bestätigte insbesondere die Tatsache, dass nigerianische Jugendliche diesen Technologien von Geodatenund Künstlicher Intelligenz (auf Englisch: Geospatial Data and Artificial Intelligence Technologies, GDAIT abgekürzt) übermäßig ausgesetzt sind, und zwar in einem Ausmaß, dass sie ihre Wahrnehmung der sozialen Beziehungen negativ beeinflussen. Dies ist sehr besorgniserregend für die Stabilität der ehemals friedlichen und anthropozentrischen traditionellen afrikanischen bzw. nigerianischen Konstellation. Diese Veränderungen in der sozialen Kommunikation sind auch von besonderer Bedeutung für die Entwicklung fremder sozialer Praktiken, die mit der negativen Wahrnehmung der sozialen Beziehungen durch nigerianische Jugendliche einhergehen können. Dentzel wiederum stellte fest, dass digitale Technologien eine wichtige Rolle bei der Befähigung von Individuen und Gemeinschaften spielen, daher wird von der Anwendung dieser Technologien "erwartet, dass sie die Produktivität und Wettbewerbsfähigkeit steigern, Bildungs- und Kultursysteme verändern, den sozialen Austausch anregen und Institutionen demokratisieren". Nichtsdestotrotz ermöglichen diese lobenswerten Technologien und ihre Rolle auch die Verschmutzung der Köpfe und die Störung der sozialen Beziehungen in Rekordzeit. Digitaler Analphabetismus kann ein ernsthaftes Problem in Ländern mit geringer Infrastruktur wie Nigeria darstellen, wo es keine adäquaten Werkzeuge zum Filtern und Zensieren von Informationen gibt und wo Kinder, Jugendliche und Erwachsene nicht einmal über die erforderliche Medien- und Informationskompetenz (Media and Information Literacy (MIL)) verfügen, um den Unterschied zwischen "Fake News" und zuverlässigen Nachrichten zu erkennen. Die Tendenz geht dahin, dass es zu einem Aufschwung jugendlichen Überschwangs kommt, da die Jugendlichen durch diese elektronischen Medien leicht veröffentlichen und sich weithin positiv oder negativ äußern können, frei von jeglichen finanziellen Zwängen. Diese überschwänglichen Verhaltensweisen haben definitiv schwerwiegende Auswirkungen auf die sozialen Praktiken und die soziale Stabilität in Nigeria. Diese Studie untersucht die Beziehung zwischen der Nutzung von Geodaten und Technologien der künstlichen Intelligenz (GDAIT) durch nigerianische Jugendliche und der Entwicklung sozialer Praktiken. Als theoretischer Rahmen für die Studie dienen die Theorien der Kultivierung Gerbners, des Beobachtungslernens Banduras 
und des technologischen Determinismus Veblens. Da Bildung der größte Sozialisationsfaktor für Jugendliche ist und junge erwachsene Studierende die größten Nutzer moderner, auf Künstlicher Intelligenz basierender digitaler Werkzeuge sind, sind Hochschulen logischerweise der beste und fruchtbarste Boden, um den Einfluss von GDAIT auf die Sozialisation zu untersuchen und die Entwicklung sozialer Praktiken unter Jugendlichen zu beobachten. Daher wurde eine Umfrage unter 300 Studenten in Abuja, der Bundeshauptstadt Nigerias, durchgeführt, um Informationen von den Jugendlichen mit Hilfe der sog Technik geschichtetes Zufallsstichprobenverfahrens (Stratified Random Sampling) zu erhalten. Die Ergebnisse werden mittels geeigneter statistischer Methoden, im Wesentlichen SPSS, analysiert, um die Beziehung zwischen der Nutzung von Geodaten und Technologien der künstlichen Intelligenz (GDAIT) durch nigerianische Jugendliche und der Entwicklung sozialer Praktiken zu ermitteln. Im Anschluss an die Umfrageergebnisse werden nützliche, konstruktive und einschränkende Empfehlungen gegeben, um den schädlichen Einfluss der Nutzung von Geodaten und Technologien der Künstlichen Intelligenz auf die soziopolitische Ordnung zu mindern.

\section{INDEX}

Schlüsselwörter: Künstliche Intelligenz, Geodaten, Entwicklung sozialer Praktiken, soziale Medien, gesellschaftspolitische Entwicklung

Mots-clés: Intelligence artificielle, données géospatiales, évolution des pratiques sociales, médias sociaux, développement socio-politique.

Keywords: Artificial Intelligence, Geospatial Data, Evolution of Social Practices, Social Media, Socio-political Development

\section{AUTHORS}

\section{CHIDINMA HENRIETTA ONWUBERE}

Department of Mass Communication, National Open University of Nigeria, Abuja

\section{HENRY 0. OSUJI}

Hydroceutical Research, FNIEB Hydroceuticals, Rennes, France 